\title{
Angler-Caught Piscivore Diets Reflect Fish Community Changes in Lake Huron
}

\author{
Edward F. Roseman* and Jeffrey S. Schaeffer \\ U.S. Geological Survey, Great Lakes Science Center, 1451 Green Road, Ann Arbor, \\ Michigan 48105, USA
}

\section{Ethan Bright}

U.S. Geological Survey, Great Lakes Science Center, 1451 Green Road, Ann Arbor, Michigan 48105, USA; and School of Natural Resources and Environment, University of Michigan, 440 Church Street, Ann Arbor, Michigan 48109, USA

\section{David G. Fielder}

Michigan Department of Natural Resources, Fisheries Research Station-Alpena, 160 East Fletcher Street, Alpena, Michigan 49707, USA

\begin{abstract}
Examination of angler-caught piscivore stomachs revealed that Lake Trout Salvelinus namaycush, Chinook Salmon Oncorhynchus tshawytscha, and Walleyes Sander vitreus altered their diets in response to unprecedented declines in Lake Huron's main-basin prey fish community. Diets varied by predator species, season, and location but were nearly always dominated numerically by some combination of Alewife Alosa pseudoharengus, Rainbow Smelt Osmerus mordax, Emerald Shiner Notropis atherinoides, Round Goby Neogobius melanostomus, or terrestrial insects. Rainbow Trout Oncorhynchus mykiss (steelhead), Coho Salmon Oncorhynchus kisutch, and Atlantic Salmon Salmo salar had varied diets that reflected higher contributions of insects. Compared with an earlier (1983-1986) examination of angler-caught predator fishes from Lake Huron, the contemporary results showed an increase in consumption of nontraditional prey (including conspecifics), use of smaller prey, and an increase in insects in the diet, suggesting that piscivores were faced with chronic prey limitation during this study. The management of all piscivores in Lake Huron will likely require consideration of the pervasive effects of changes in food webs, especially if prey fish remain at low levels.
\end{abstract}

Freshwater piscivores have the ability to alter prey behavior (Werner and Hall 1988), structure prey communities (Zaret and Paine 1973; Mittlebach et al. 1995), and alter production via top-down effects (Carpenter and Kitchell 1988). Piscivore effects have been especially strong in the Laurentian Great Lakes, where fisheries managers introduced nonnative Pacific salmon Oncorhynchus spp. during the 1960s to control Alewives Alosa pseudoharengus and consume Rainbow Smelt Osmerus mordax (Kocik and Jones 1999; Tanner and Tody 2002), both nonnative planktivores (Aron and Smith 1971).
Alewives had proliferated to nuisance levels in Lakes Huron and Michigan after the near extirpation of native predators (Smith 1970; Brown 1972). The Pacific salmon introduction was also concurrent with efforts to restore native Lake Trout Salvelinus namaycush via stocking (Hansen 1999).

The introduction of Pacific salmon created a novel predatorprey system. Originally, the native prey fish community in Lake Huron supported Lake Trout, Walleyes Sander vitreus, and Burbot Lota lota as the main predators. Prey consisted of seven species of deepwater Ciscoes Coregonus spp., Sculpins Cottus spp.,

*Corresponding author: eroseman@usgs.gov

Received December 19, 2013; accepted June 30, 2014 
Deepwater Sculpins Myoxocephalus thompsonii (Eshenroder and Burnham-Curtis 1999) and smaller numbers of Lake Whitefish Coregonus clupeaformis, Round Whitefish Prosopium cylindraceum, Ninespine Sticklebacks Pungitius pungitius, Trout-perch Percopsis omiscomaycus, Spottail Shiners Notropis hudsonius, Emerald Shiners Notropis atherinoides, Lake Chub Coeusius plumbeus, White Suckers Catostomus commersonii, and Longnose Suckers Catostomus catostomus (Spangler and Collins 1992; Ebener et al. 1995; Roseman et al. 2009). Native species were still present (although likely in reduced numbers in the presence of Alewives; Bunnell et al. 2006) but were nearly absent in piscivore diets (Diana 1990). Pacific salmon and Lake Trout preyed almost exclusively on Alewives or Rainbow Smelt (Diana 1990).

The predator-prey system continued to support a popular sport fishery (Kocik and Jones 1999) that achieved Alewife suppression (Madenjian et al. 2002), but subsequent ecosystem-wide changes disrupted existing food webs. Although the mechanisms are not well understood, invasion by zebra and quagga mussels Dreissena spp. beginning circa 1990 may have shunted energy or nutrients away from native species (Hecky et al. 2004; McNickle et al. 2006); their proliferation was followed temporally by prey fish community collapse (Riley et al. 2008; Roseman and Riley 2009), increased water clarity and macrophytes (Fahnenstiel et al. 1995; Budd et al. 2001), loss of large macroinvertebrates (Nalepa et al. 2007), and shifts in zooplankton community composition (Barbiero et al. 2009; Bunnell et al. 2011). There was also a concurrent invasion by Round Goby Neogobius melanostomus (Jude and DeBoe 1996; Schaeffer et al. 2005).

The most striking change, however, was the near collapse of Alewives during 2002-2004, which entailed an $87 \%$ reduction in both abundance and biomass (Riley et al. 2008; Roseman and Riley 2009); this was associated temporally with decreased Chinook Salmon abundance (Johnson and Gonder 2013). Following the Alewife collapse, prey fish biomass was reduced substantially and remained low through 2013 (Riley et al. 2014). This created a prey community comprised of smaller-sized and less-abundant Rainbow Smelt, Round Goby, and native species (Riley et al. 2014) that was supporting lower numbers of stocked Pacific salmon and a growing number of wild Pacific salmon, Lake Trout, and Walleyes.

The changes to the Lake Huron fish community occurred at an unprecedented pace with the collapse of the prey community between 2002 and 2004, and there was great concern as to whether the forage base was large enough to meet the food requirements of the piscivores. A previous study (Diana 1990) used angler-caught fish (1983-1986) to characterize predator diets prior to the food web shift of the 2000s. We replicated this work by examining the diets of angler-caught piscivores collected in western Lake Huron (Michigan waters; Figure 1) during 2009-2011 to assess predator responses to changes in the

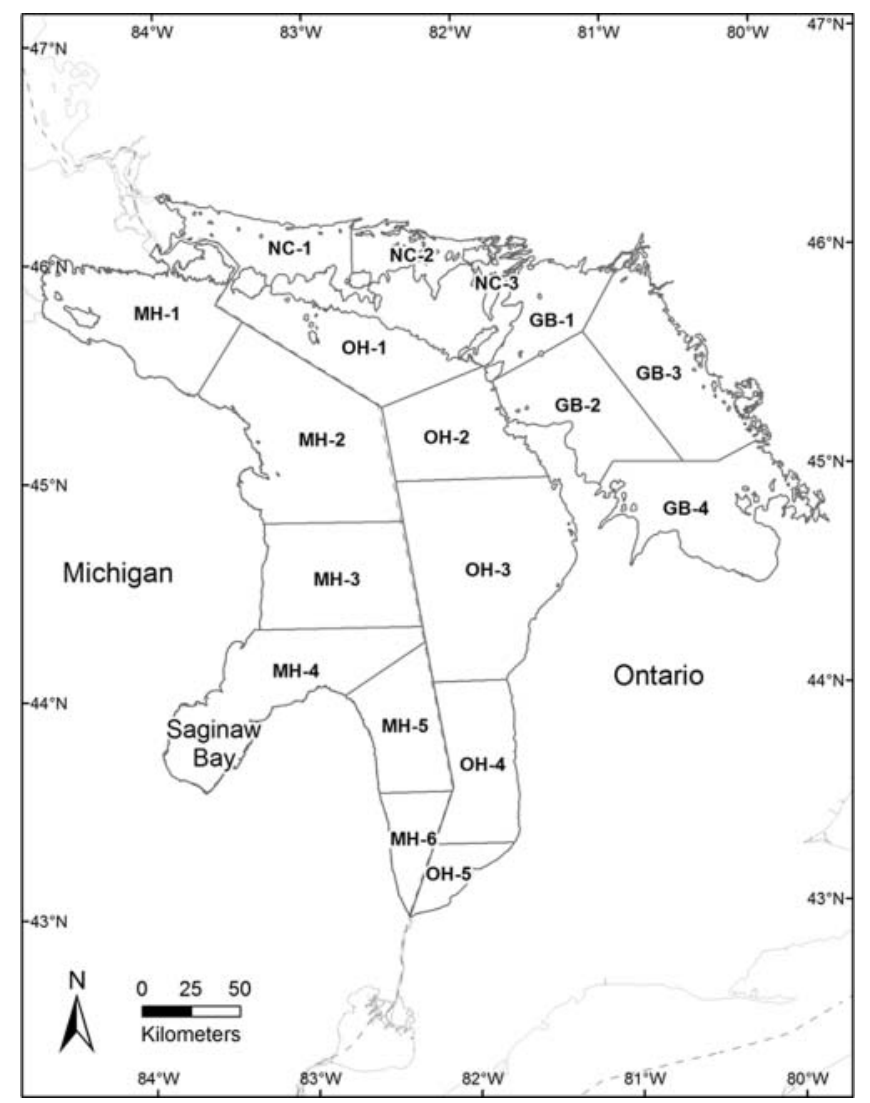

FIGURE 1. Map of Lake Huron showing the statistical districts used to categorize sample collection locations.

prey base and compared those results with those of Diana (1990).

\section{METHODS}

Stomachs were obtained from fish harvested by recreational anglers on Lake Huron during May-October, 2009, 2010, and 2011. Most samples were provided by anglers from the offshore troll fishery (trolling is an angling method in which lines baited with lures are drawn through the water by boat). We occasionally collected stomachs directly from anglers at fishing tournaments and from high-traffic fish cleaning stations near marinas. During 2010 and 2011, many fishing clubs organized collections via their tournaments. We also received assistance from Michigan Department of Natural Resources creel survey clerks, who collected samples from anglers during their interviews as part of state-run creel surveys.

Whole stomachs and viscera were excised from harvested fish at the time of capture or cleaning, and each intact stomach was placed in a plastic bag and frozen along with a preprinted label on which anglers recorded the predator species, capture date, total length, and fishing location (nearest port). Frozen stomachs were periodically collected from anglers directly or from centralized freezer locations (often at marinas), 
transported to the laboratory, thawed, and examined. Samples were excluded if multiple stomachs were bagged together, if species or length data were missing, or if the capture location could not be determined. Because capture locations varied, we aggregated samples by ascribing them to the management district from which the fish were captured (Figures 1,2). This provided the highest degree of spatial certainty, maintained sample size for analysis of temporal and spatial differences, and allowed us to include samples for which the capture location was described broadly (usually the port of trip origin).

All fish prey were identified to the lowest practical taxonomic level, usually species. Partially digested prey were identified using a variety of digestion-resistant characteristics (Elliot et al. 1996), and we found that even highly digested prey could be identified via cleithra (Traynor et al. 2010). The total length (TL), standard length (SL), or backbone length (BB) of each intact prey fish was measured (mm), depending on the state of digestion. We estimated weight at capture for fish prey using published total length-weight relationships, with total length being either measured directly or predicted from standard or intact backbone lengths (e.g., Knight et al. 1984; Schneider 2000). For some prey species not reported in prior studies, we derived length-weight relationships using archived data from U.S. Geological Survey (USGS) long-term trawl surveys. No SL-TL or BB-TL relationships existed for some rare prey species. In those cases, we assumed ratios of $1.2(\mathrm{TL} / \mathrm{SL})$ or $1.5(\mathrm{TL} / \mathrm{BB})$ to estimate the total length at capture based on relationships from Knight et al. (1984).

Invertebrates were always identified to at least order but in some cases to family or genus. Initially, invertebrates were counted (2009), but their dietary prevalence led us to measure the wet weights (g) of each type directly (2010-2011) after they were sorted to taxonomic group and blotted dry. For the 2009 data, counts were converted to wet weights using published values (Wilmer and Unwin 1981) or archived data from USGS long-term benthic surveys. Earthworms Lumbricus terrestris found in Walleyes were excluded due to their prevalence as bait.

We enumerated the contents of individual stomachs using both the frequency of occurrence and the percent contribution of each prey type to total diet weight. Almost all predators consumed a mixed diet that included both invertebrates and fish whose weights differed by several orders of magnitude; hence, we compared dietary differences among predators by comparing differences in the weights of each prey group among predators using analysis of variance (ANOVA), after first normalizing the weight measurements with a $\log$ transformation and adding a small coefficient (0.003) to account for cases in which identifiable prey were present but too digested for us to obtain their weight. In cases in which ANOVA indicated significant differences among independent variables $(P \leq 0.05)$, we examined among-treatment differences using Tukey-Kramer tests (SAS Institute 2011). To simplify the analyses for comparison with those of Diana (1990), we also
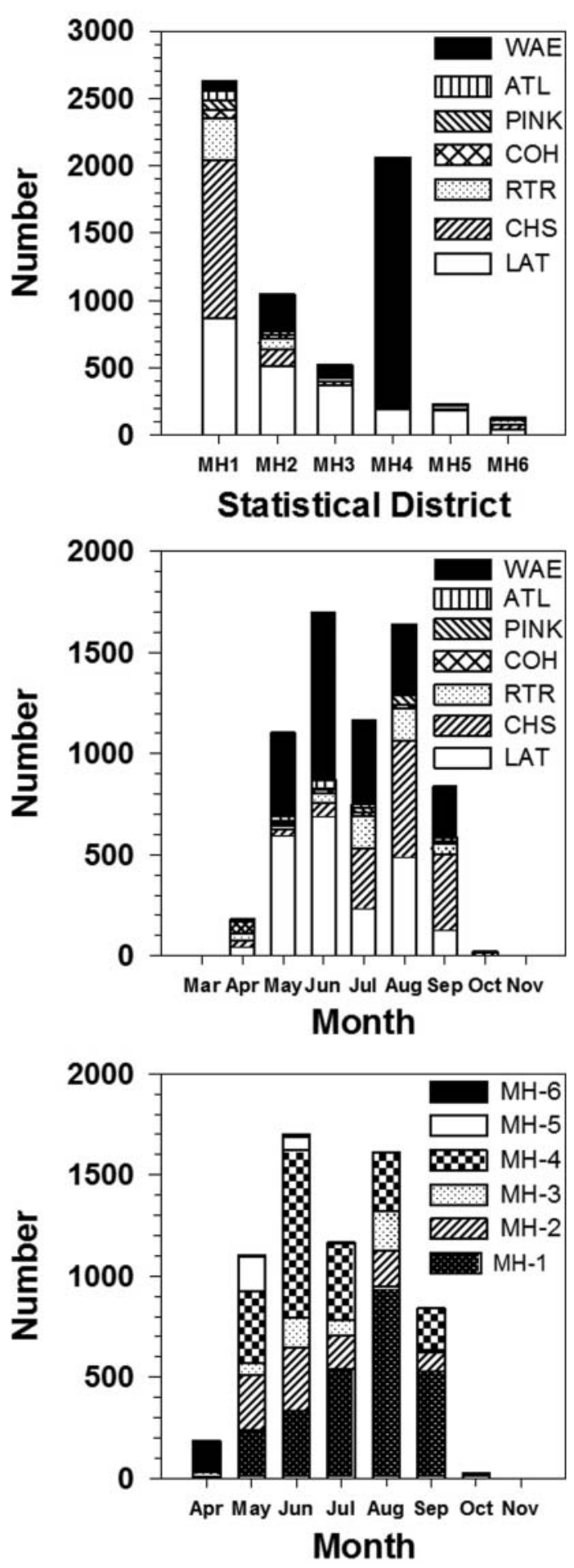

FIGURE 2. Spatial and temporal distributions of 6,713 piscivorous fish captured in Lake Huron, 2009-2011 (top panel: spatial distribution of species; middle panel: temporal distribution of species; bottom panel: temporal distribution by statistical district). Species abbreviations are as follows: LAT $=$ Lake Trout, $\mathrm{WAE}=$ Walleye, $\mathrm{CHS}=$ Chinook Salmon, $\mathrm{RTR}=$ Rainbow Trout, $\mathrm{COH}=$ Coho Salmon, PINK $=$ Pink Salmon, and ATL $=$ Atlantic Salmon. Northern Pike, Splake, and Brook Trout are not shown due to their small sample sizes; months and districts with sample sizes of fewer than five fish are not visible. 
pooled prey into the following classes: Alewives, Rainbow Smelt, salmonids, Round Goby, Yellow Perch, other fish species, and invertebrates. We also estimated stomach fullness (Hyslop 1980) as a way to compare ration size among predators of different sizes. Ration size was calculated by dividing the wet weight of the prey in stomachs (measured directly for invertebrates and estimated at capture for fish prey) by the predator weight predicted from length-weight relationships.

We compared our results directly with those of Diana (1990), who collected 1,833 angler-caught salmonids during 19831986. Comparisons were limited to species common to both studies. As no Atlantic Salmon Salmo salar or Walleyes were reported by that study, we excluded those species. Where numerical data were available from the 1983-1986 study, we performed statistical comparisons using chi-square tests; where no numerical data were available, we made only qualitative comparisons.

\section{RESULTS}

Anglers provided 6,935 stomachs during 2009-2011, for which 6,713 had complete information on capture and food presence or absence. Lake Trout, Walleyes, and Chinook Salmon were the most common species sampled, with smaller numbers of steelhead (anadromous Rainbow Trout), Coho Salmon, Pink Salmon, and Atlantic Salmon (Table 1). Brown Trout, Northern Pike, Splake, and Brook Trout were rare $(N<$ $50)$ and were excluded from most analyses.

The proportion of stomachs containing food varied among species. At least $62 \%$ of Rainbow Trout, Coho Salmon, Pink Salmon, and Atlantic Salmon contained food, with Atlantic
Salmon having the highest frequency of food presence (74\%). About half (51\%) of Lake Trout stomachs contained food, but that was true for only $41 \%$ of Chinook Salmon. Walleyes had the lowest food presence (28\%), possibly because most were captured in Saginaw Bay where warm water temperatures may have supported faster digestion. Several anglers reported observing regurgitation by hooked Walleyes just prior to landing. The proportions of full and empty stomachs varied little among years (Table 1).

Of the 6,713 fish with complete information, 6,666 had stomachs that were both intact and preserved enough to process. Of these, 2,909 (43.6\%) provided 12,720 distinct observations of prey categorized as individual fish or pooled invertebrate types. There were 617 unidentifiable prey (4.9\%), which were excluded from further analysis. The proportion of prey excluded varied from 3\% to 5\% among species, but higher numbers of Pink Salmon $(8.3 \%)$ and Walleyes $(17.1 \%)$ were excluded.

The spatial and temporal distributions of the collections were not uniform because the fishery changed seasonally. Anglers generally began fishing southern Lake Huron in April and moved north as the spring and summer progressed. About $6 \%$ of the fish were obtained from southern Lake Huron. Catches during May and June were dominated by Lake Trout and Walleyes, while most Rainbow Trout and Chinook Salmon were collected during July-September, with the majority being obtained from northern Lake Huron (statistical districts MH-1 and MH-2; Figure 2). Slightly over $80 \%$ of Walleyes were collected from the MH-4 district, which encompasses Saginaw Bay. The temporal differences in Walleye sample sizes were minimal because Walleyes were harvested during most months.

TABLE 1. Sample sizes for predators collected by anglers from Lake Huron, 2009-2011. Species are listed in order of abundance; F = fed (i.e., contained prey), $\mathrm{E}=$ empty stomach.

\begin{tabular}{|c|c|c|c|c|c|c|c|c|}
\hline \multirow[b]{3}{*}{ Species } & \multicolumn{6}{|c|}{ Year } & \multirow[b]{3}{*}{ Percent with food } & \multirow[b]{3}{*}{ Tota } \\
\hline & \multicolumn{2}{|c|}{2009} & \multicolumn{2}{|c|}{2010} & \multicolumn{2}{|c|}{2011} & & \\
\hline & $\mathrm{F}$ & E & $\mathrm{F}$ & E & $\mathrm{F}$ & $\mathrm{E}$ & & \\
\hline Lake Trout & 379 & 469 & 480 & 400 & 255 & 205 & 50.9 & 2,188 \\
\hline Walleye & 150 & 398 & 310 & 911 & 178 & 318 & 28.1 & 2,265 \\
\hline Chinook Salmon Oncorhynchus tshawytscha & 135 & 244 & 196 & 263 & 239 & 308 & 41.1 & 1,385 \\
\hline Rainbow Trout $O$. mykiss & 70 & 17 & 188 & 65 & 90 & 48 & 72.8 & 478 \\
\hline Coho Salmon $O$. kisutch & 16 & 7 & 44 & 25 & 21 & 16 & 62.7 & 129 \\
\hline Pink Salmon $O$. gorbuscha & 4 & 4 & 61 & 29 & 11 & 5 & 66.6 & 114 \\
\hline Atlantic Salmon & 38 & 8 & 29 & 14 & 7 & 4 & 74.0 & 100 \\
\hline Brown Trout Salmo trutta & 3 & 1 & 6 & 8 & 18 & 6 & & 42 \\
\hline Northern Pike Esox lucius & 2 & 4 & & & & & & 6 \\
\hline Splake $^{\mathrm{a}}$ & & 1 & 3 & 1 & & & & 5 \\
\hline Brook Trout & & & 1 & & & & & 1 \\
\hline Annual percent & 40.9 & 59.1 & 43.4 & 56.6 & 47.4 & 52.6 & 43.7 & \\
\hline Total & 797 & 1,153 & 1,318 & 1,716 & 819 & 910 & & 6,713 \\
\hline
\end{tabular}

${ }^{\mathrm{a}}$ Brook Trout Salvelinus fontinalis $\times$ Lake Trout. 


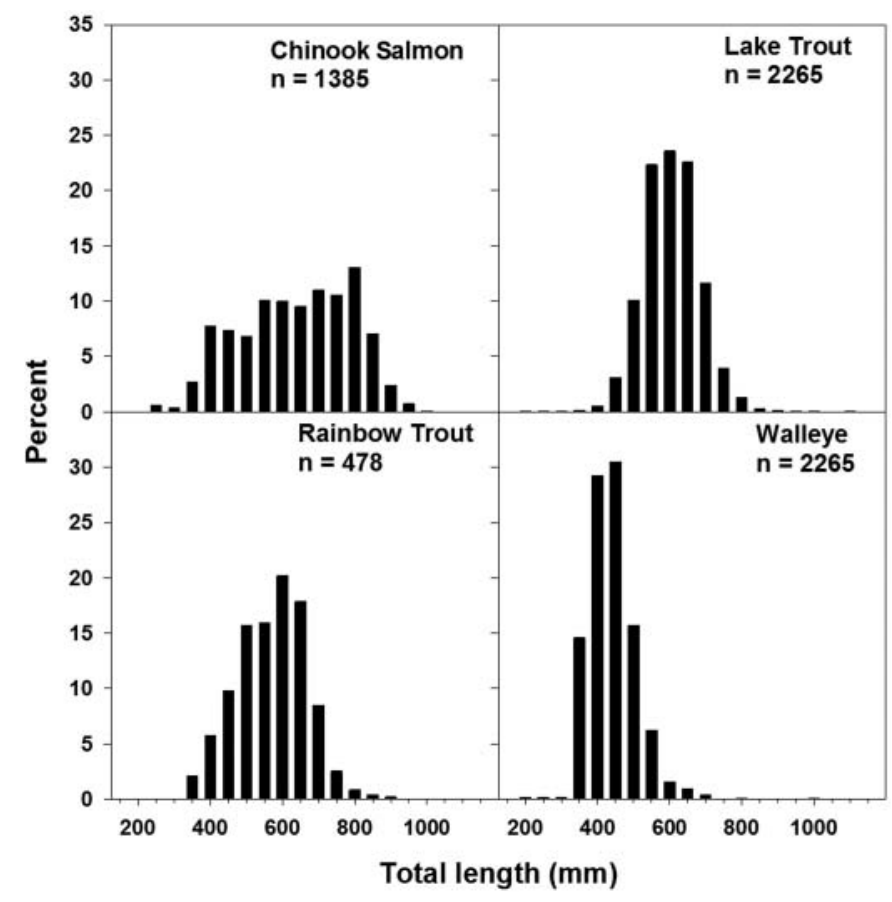

FIGURE 3. Length frequency distributions of angler-caught Chinook Salmon, Lake Trout, Rainbow Trout, and Walleyes from Lake Huron, 20092011.

Anglers nearly always collected fish larger than the minimum length limits. Length frequency distributions were truncated by the minimum legal harvest lengths, which were $381 \mathrm{~mm}$ for Walleye and Lake Trout and $254 \mathrm{~mm}$ for Pacific salmonids (Michigan DNR 2014). For all years combined, $94 \%$ of the predators sampled ranged from 400 to $800 \mathrm{~mm}$ TL (Figure 3).

\section{Frequency of Occurrence}

Stomach samples contained 29 species of fish (Table 2) and 6 general groups of invertebrates: dreissenid mussels, aquatic insects (the nymphs or adults of mayflies, caddis flies, and midges), opossum shrimp, crayfish, terrestrial insects (multiple orders, but often beetles or ants), and spiny water fleas. However, diets nearly always had some combination of Alewives, Rainbow Smelt, Emerald Shiners, Round Goby, or terrestrial insects (Figures 4, 5). The most common prey of Lake Trout in our study was Round Goby, followed by Rainbow Smelt. About 5\% of stomachs contained other salmonids, predominantly as a result of cannibalism. Lake Trout also consumed 14 prey types that were rarely or never eaten by other predators, but most represented single occurrences. Chinook Salmon consumed predominantly Rainbow Smelt and lower numbers of Alewives, sticklebacks, and Round Goby. About $21 \%$ of their stomachs contained spiny water fleas that likely represented volitional consumption (Jacobs et al. 2013). Terrestrial insects constituted the bulk of Rainbow Trout diets, and Alewives, Rainbow Smelt, and Ninespine Sticklebacks were the most frequently observed fish prey. Coho Salmon consumed primarily Emerald Shiners and Rainbow Smelt, and insects comprised about $15 \%$ of their diet. The only common fish prey in Pink Salmon diets was Rainbow Smelt; they also consumed terrestrial insects (13.9\%) and had the highest incidence of spiny water fleas. Atlantic Salmon differed from other salmonids in that they more frequently consumed sticklebacks (21.4\% of stomachs). In contrast to salmonids, Walleyes consumed primarily Yellow Perch, Emerald Shiners, and Round Goby; numerically, these three species comprised about $71 \%$ of their prey.

\section{Dietary Mass}

For fish prey, the percent contribution to total dietary mass was positively correlated with frequency of occurrence $\left(r^{2}=\right.$ $0.73, P<0.05)$, although wet weight contributions varied among predators. The proportion by weight of Lake Trout diets was dominated by Rainbow Smelt and Round Goby, which contributed about $69 \%$ of total dietary wet weight (Table 3; Figure 5). Alewives contributed 6.8\%, which was less than Bloater $(8.6 \%)$ or other salmonids $(>9.0 \%)$. Other fish species contributed no more than about $1 \%$ by weight, often because they represented single or few $(<5)$ captures. In contrast, Alewives (62\%) and Rainbow Smelt (26\%) contributed the largest prey mass to Chinook Salmon, while no other species exceeded a $4 \%$ contribution. Insects were the largest proportion of dietary mass consumed by Rainbow Trout (50.9\%), followed by Alewives $(13.5 \%)$ and Rainbow Smelt (7.5\%). Coho Salmon consumed a greater proportion of Emerald Shiners than any other predator (25.9\%), and they had the second highest proportion of terrestrial insects (25.9\%). Pink Salmon consumed the highest proportion by weight of spiny water fleas $(6.9 \%)$ and also consumed an appreciable quantity of terrestrial insects (16.2\%), but Rainbow Smelt were their most important prey from a dietary mass perspective (57.5\%). Rainbow Smelt comprised the largest proportion of prey consumed by Atlantic Salmon $(30.1 \%)$, but their diets were distinct in that they were the only species that consumed sticklebacks $(20.2 \%)$ and sculpins $(6.8 \%)$ to any degree. Insects and crustaceans comprised slightly over $9 \%$ of their diet. Walleye diets contained Round Goby, Emerald Shiner, and Yellow Perch. Walleye stomachs contained significantly less invertebrate mass, likely because they consumed small chironomid larvae only occasionally (Figures 4,5 ).

\section{Ration Size}

We observed minor differences in ration size among species. Chinook Salmon and Coho Salmon had significantly higher ration sizes than Walleyes, Atlantic Salmon, and Pink Salmon (Tukey-Kramer test: $P<0.05$ ), while the ration size of Rainbow Trout was lower than those of other species (Figure 6). Ration 
TABLE 2. Frequency of occurrence of prey consumed by Lake Huron predators collected by anglers, 2009-2011 (all years pooled). Species abbreviations are as follows: $\mathrm{LAT}=$ Lake Trout, $\mathrm{WAE}=$ Walleyes, $\mathrm{CHS}=$ Chinook Salmon, RTR $=$ Rainbow Trout, $\mathrm{COH}=\mathrm{Coho}$ Salmon, PIN $=$ Pink Salmon, ATL $=$ Atlantic Salmon. Northern Pike, Splake, and Brook Trout are not shown due to their small sample sizes.

\begin{tabular}{|c|c|c|c|c|c|c|c|}
\hline \multirow[b]{2}{*}{ Prey species } & \multicolumn{7}{|c|}{ Predator species } \\
\hline & LAT & CHS & RTR & $\mathrm{COH}$ & PIN & ATL & WAE \\
\hline Sea Lamprey Petromyzon marinus & $<1.0$ & & & & & & \\
\hline Alewife & 2.3 & 14.8 & 8.0 & 2.2 & 4.2 & 5.1 & $<1.0$ \\
\hline Gizzard Shad Dorosoma cepedianum & & & & & & & 3.0 \\
\hline Rainbow Smelt & 28.7 & 42.2 & 17.1 & 19.3 & 33.3 & 17.3 & 3.6 \\
\hline Channel Catfish Ictalurus punctatus & $<1.0$ & & & & & & \\
\hline American Eel Anguilla rostrata & & $<1.0$ & & & & & \\
\hline Burbot & $<1.0$ & & & & & & \\
\hline Threespine Stickleback & $<1.0$ & $<1.0$ & 1.4 & & & 12.2 & \\
\hline Gasterosteus aculeatus & & & & & & & \\
\hline Ninespine Stickleback & 3.0 & 5.6 & 4.3 & 4.3 & 1.4 & 9.2 & \\
\hline Trout-perch & $<1.0$ & & $<1.0$ & & & & \\
\hline White Perch Morone americana & $<1.0$ & & $<1.0$ & & & & \\
\hline White Bass Morone chrysops & $<1.0$ & & $<1.0$ & & & & \\
\hline Lake Whitefish & $<1.0$ & & & & & & \\
\hline Bloater Coregonus hoyi & 3.3 & 1.3 & 1.0 & 1.1 & & 1.0 & $<1.0$ \\
\hline Unidentified salmonid & 1.3 & 1.2 & $<1.0$ & 2.2 & 1.4 & & 1.0 \\
\hline Chinook Salmon & $<1.0$ & $<1.0$ & $<1.0$ & 1.1 & 1.4 & 1.0 & \\
\hline Lake Trout & 2.0 & & $<1.0$ & & & 5.1 & $<1.0$ \\
\hline Coho Salmon & $<1.0$ & & $<1.0$ & 2.1 & & & \\
\hline Unidentified suckers (Catostomidae) & $<1.0$ & & & & & & \\
\hline Longnose Sucker Catostomus catostomиs & & & & & & & $<1.0$ \\
\hline Unidentified minnows (Cyprinidae) & & $<1.0$ & $<1.0$ & 1.1 & & 1.0 & 1.0 \\
\hline Silver Chub Macrhybopsis storeriana & $<1.0$ & & & & & & \\
\hline Emerald Shiner & 5.4 & 1.3 & 2.4 & 28.0 & 2.8 & 7.1 & 22.2 \\
\hline Spottail Shiner & & & & 1.1 & & & \\
\hline Creek Chub Semotilus atromaculatus & & & $<1.0$ & & & 1.0 & \\
\hline Rock Bass Ambloplites rupestris & & $<1.0$ & $<1.0$ & & & & \\
\hline Smallmouth Bass Micropterus dolomieu & & $<1.0$ & & 1.0 & & & \\
\hline Yellow Perch Perca flavescens & $<1.0$ & $<1.0$ & & 4.3 & & & 20.5 \\
\hline Unidentified sculpins (Cottidae) & $<1.0$ & & & & & $<1.0$ & $<1.0$ \\
\hline Mottled Sculpin Cottus bairdii & $<1.0$ & & & & & 1.0 & \\
\hline Slimy Sculpin Cottus cognatus & $<1.0$ & & $<1.0$ & & & 1.0 & \\
\hline Deepwater Sculpin & $<1.0$ & & & 1.1 & & 1.0 & \\
\hline Round Goby & 44.0 & 5.1 & 6.8 & 9.7 & & 12.2 & 28.1 \\
\hline Mussels Dreissena spp. & $<1.0$ & & & & & & \\
\hline Aquatic insects $^{\mathrm{a}}$ & & & 5.1 & 1.1 & 1.4 & 4.1 & 2.7 \\
\hline Opossum shrimp Mysis diluviana & & $<1.0$ & & & 1.4 & & \\
\hline Crayfish (Decapoda) & $<1.0$ & & & & & 1.0 & \\
\hline Terrestrial insects $^{\mathrm{b}}$ & 3.0 & 5.1 & 40.3 & 15.0 & 13.9 & 16.0 & 2.5 \\
\hline Midges (Chironomidae) & & & & & & 2.0 & 10.8 \\
\hline Spiny water flea Bythotrephes longimanus & 1.0 & 20.6 & 8.9 & 5.4 & 37.5 & 2.0 & $<1.0$ \\
\hline
\end{tabular}

${ }^{a}$ Adult life stages, predominantly mayflies (Ephemeroptera) and caddis flies (Trichoptera).

${ }^{\mathrm{b}}$ Multiple orders, including beetles (Coleoptera), ants (Hymenoptera), and butterflies (Lepidoptera). 


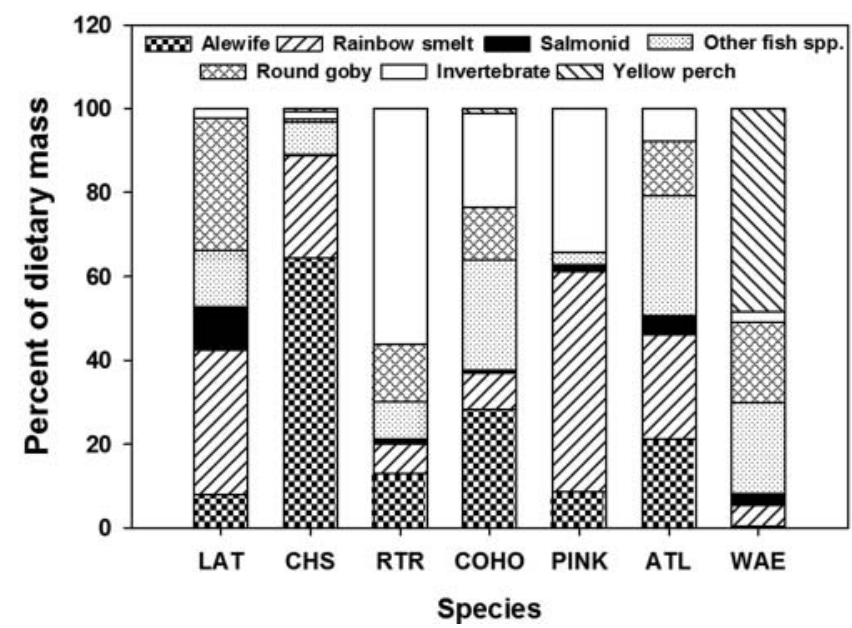

FIGURE 4. Percent contribution by mass of different prey groups to piscivore diets collected from Lake Huron during 2009-2011 (all samples pooled within species). See Figure 2 for species abbreviations and additional details.

size differed among years for Chinook Salmon, Lake Trout, and Walleyes (the three species for which sample sizes were adequate for among-year comparisons). We observed substantive among-year variation in ration size as well as among individual prey groups (among-year differences in the contribution of particular prey types to total dietary mass) for all three species for which we had adequate sample sizes. For Lake Trout, mean ration size was significantly different among all study years, being highest during 2011 due to an increase in the dietary weight of Alewives and reductions in the dietary weights of Round Goby, Rainbow Smelt, and salmonids (Tukey-Kramer test: $P<0.05$; Figure 6). Chinook Salmon diets followed a similar pattern, but the significantly higher mean prey weight during 2011 was associated with an increase in Alewives combined with reductions in both Rainbow Smelt and other species $(P<$ $0.05)$. The mean ration in Walleye stomachs increased significantly during 2011 and was associated with higher dietary proportions of Yellow Perch $(P<0.05)$.

We found little evidence of size selectivity. There was no relationship between prey total length and predator length for Lake Trout or Walleyes (separate regressions; $P \geq 0.05$ ). There was a positive relationship for Chinook Salmon $\left(r^{2}=0.12 ; P<\right.$ 0.05 ) but the regression explained little of the variability, likely because even large fish consumed prey less than $100 \mathrm{~mm}$ TL.

The prey size distributions during 2009-2011suggest that large prey were extremely rare. Only 98 (1.1\%) of the 8,961 measurable fish prey that we found in stomachs exceeded $150 \mathrm{~mm}$ TL at capture (Figures 7, 8) and about half did not exceed $50 \mathrm{~mm}$. Species composition differed among prey size-classes. Below $150 \mathrm{~mm}$ TL, diets were generally dominated by Rainbow Smelt or Round Goby, but the large ( $>150 \mathrm{~mm} \mathrm{TL}$ ) prey items found in stomachs were predominantly salmonids, Alewives, and other fish species that tended to be numerically rare in diets.
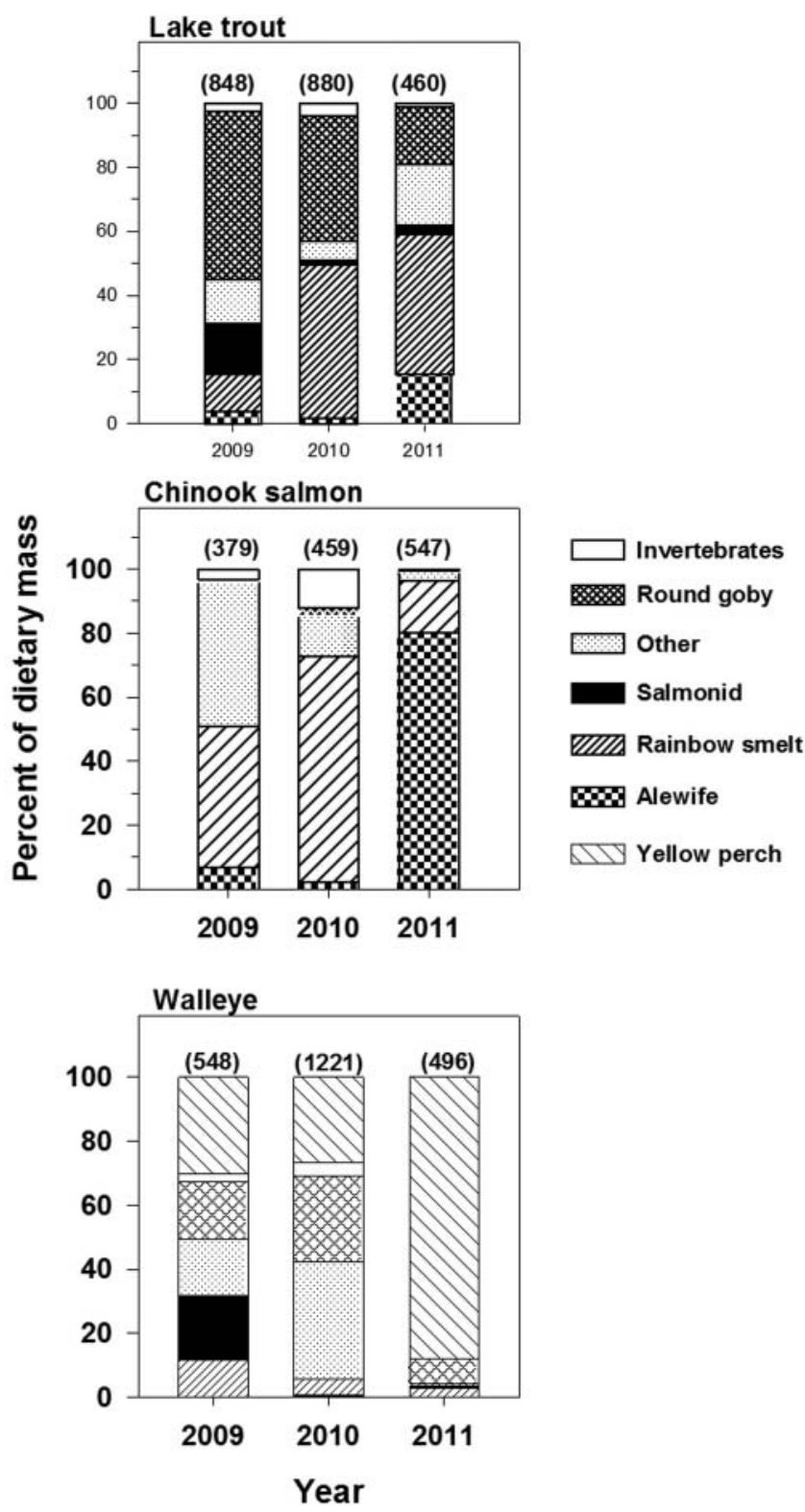

FIGURE 5. Year-to-year variation in diets of Lake Trout, Chinook Salmon, and Walleyes with grouped prey categories, Lake Huron, 2009-2011 (all samples pooled within species).

\section{DISCUSSION}

Most piscivores in Lake Huron have altered their diets since the 1990 study, each in a slightly different way. Based on the samples we examined, Lake Trout now consume Round Goby, Rainbow Smelt, and other fish in approximately equal proportions, whereas Diana (1990) observed roughly equal proportions of Alewives and Rainbow Smelt. Rainbow Trout, Coho Salmon, Pink Salmon, and Atlantic Salmon consumed both invertebrates and a variety of fish prey. Walleyes consumed Yellow Perch, Emerald Shiners, and Round Goby. In contrast, Chinook Salmon diets appear to have varied little. Diana (1990) observed that they consumed Rainbow Smelt and 
TABLE 3. Percent by weight of prey consumed by Lake Huron predators collected by anglers, 2009-2011 (all years pooled). See Table 2 for species abbreviations and additional details.

\begin{tabular}{|c|c|c|c|c|c|c|c|}
\hline \multirow[b]{2}{*}{ Prey species } & \multicolumn{7}{|c|}{ Predator species } \\
\hline & LAT & CHS & RTR & $\mathrm{COH}$ & PIN & ATL & WAE \\
\hline Sea Lamprey & $<1.0$ & & & & & & \\
\hline Alewife & 6.8 & 62.2 & 13.5 & 15.1 & 9.5 & 5.1 & $<1.0$ \\
\hline Gizzard Shad & & & & & & & 4.4 \\
\hline Rainbow Smelt & 36.1 & 26.0 & 7.5 & 10.6 & 57.5 & 30.1 & 5.3 \\
\hline Channel Catfish & $<1.0$ & & & & & & \\
\hline American Eel & & $<1.0$ & & & & & \\
\hline Burbot & $<1.0$ & & & & & & \\
\hline Threespine Stickleback & $<1.0$ & $<1.0$ & $<1.0$ & & & 4.3 & \\
\hline Ninespine Stickleback & $<1.0$ & 2.5 & 2.7 & 1.0 & 1.4 & 15.9 & \\
\hline Trout-perch & $<1.0$ & & $<1.0$ & & & & \\
\hline White Perch & $<1.0$ & & 1.5 & & & & \\
\hline White Bass & $<1.0$ & & $<1.0$ & & & & \\
\hline Lake Whitefish & $<1.0$ & & & & & & \\
\hline Bloater & 8.6 & 4.0 & $<1.0$ & $<1.0$ & & $<1.0$ & $<1.0$ \\
\hline Unidentified salmonids & 1.1 & $<1.0$ & $<1.0$ & & 6.5 & & 1.32 \\
\hline Chinook Salmon & 1.8 & $<1.0$ & $<1.0$ & $<1.0$ & & $<1.0$ & \\
\hline Lake Trout & 6.4 & & $<1.0$ & & & 4.6 & 1.8 \\
\hline Coho Salmon & $<1.0$ & & $<1.0$ & $<1.0$ & & & \\
\hline Unidentified suckers & $<1.0$ & & & & & & \\
\hline Longnose Sucker & & & & & & & $<1.0$ \\
\hline Unidentified minnows & & $<1.0$ & $<1.0$ & $<1.0$ & & & $<1.0$ \\
\hline Silver Chub & $<1.0$ & & & & & & \\
\hline Emerald Shiner & $<1.0$ & $<1.0$ & $<1.0$ & 25.9 & 1.8 & 6.1 & 7.5 \\
\hline Spottail Shiner & & & & 3.1 & & & \\
\hline Creek Chub & & & $<1.0$ & & & 1.2 & \\
\hline Rock Bass & & $<1.0$ & 1.8 & & & & \\
\hline Smallmouth Bass & & $<1.0$ & & $<1.0$ & & & \\
\hline Yellow Perch & $<1.0$ & $<1.0$ & & 1.4 & & & 52.0 \\
\hline Unidentified sculpins & $<1.0$ & & & & & $<1.0$ & 3.4 \\
\hline Mottled Sculpin & $<1.0$ & & & & & 5.1 & \\
\hline Slimy Sculpin & $<1.0$ & & $<1.0$ & & & & \\
\hline Deepwater Sculpin & $<1.0$ & & & $<1.0$ & & 1.7 & \\
\hline Round Goby & 33.2 & 1.0 & 14.4 & 14.9 & & 15.7 & 20.5 \\
\hline Mussels & $<1.0$ & & & & & & \\
\hline Aquatic insects & & & 3.6 & $<1.0$ & $<1.0$ & 2.2 & $<1.0$ \\
\hline Opossum shrimp & & $<1.0$ & & & $<1.0$ & & \\
\hline Crayfish & $<1.0$ & & & & & 1.8 & \\
\hline Terrestrial insects & 1.2 & 1.4 & 47.3 & 25.9 & 16.2 & 5.2 & $<1.0$ \\
\hline Midges & & & & & & & 1.8 \\
\hline Spiny water flea & $<1.0$ & $<1.0$ & $<1.0$ & $<1.0$ & 6.9 & $<1.0$ & $<1.0$ \\
\hline
\end{tabular}

Alewives almost exclusively; we found that those two species occurred in 57\% of Chinook Salmon stomachs and represented about $88 \%$ of dietary mass. For salmonids, large prey seemed especially rare. The large $(>150-\mathrm{mm})$ prey size-classes observed in Diana's (1990) study were absent (most fish subsisting on small prey), and we found little evidence of relationships between predator size and prey size. The large prey items in diet samples were Alewives (which were rare except during 2011) or atypical prey species such as adult Burbot, Channel Catfish, and other salmonids. We found little evidence that piscivores were able to compensate for reduced size by consuming more individuals. Following the prey 

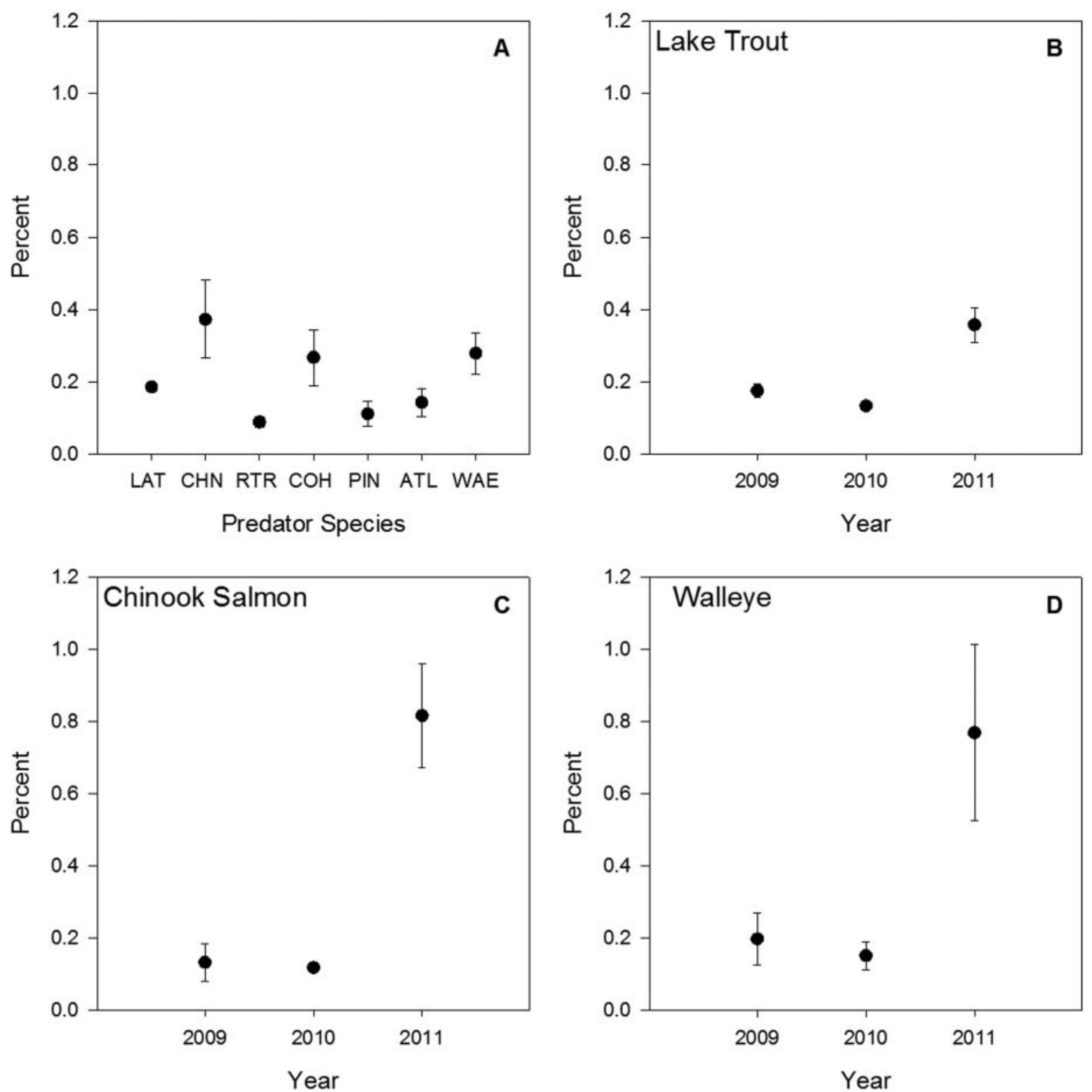

FIGURE 6. Mean ration size (percent of body weight) of predators in Lake Huron, 2009-2011. Panel (A) shows the ration sizes for seven predator species (Northern Pike, Splake, and Brook Trout are not shown due to their small sample sizes). Panels (B)-(D) show annual estimates of ration size for Lake Trout, Chinook Salmon, and Walleyes. The error bars indicate the 95\% confidence intervals. See Figure 2 for species abbreviations.

community collapse in 2003, prey abundance has remained low and dominated by small $(<150-\mathrm{mm})$ Rainbow Smelt, Bloaters, and Round Goby (Riley et al. 2014).

Chinook Salmon have been regarded as obligate pelagic predators, and our data reinforce this. Lake Huron Chinook Salmon relied heavily on Rainbow Smelt both in the 1980s (Diana 1990) and during 2009-2011, and they did not change their foraging strategy, as has been seen in other studies (Stewart et al. 1981; Jude et al. 1987; Warner et al. 2008; Savitz 2009). This failure to alter their strategy occurred despite the near absence of Alewives compared with the years prior to 2004 and lower Rainbow Smelt biomass compared with the 1980s (Riley et al. 2014). Other studies of Chinook Salmon diets in the Great Lakes have found a strong preference for Alewives, selection against Rainbow Smelt and Bloaters, and failure to alter foraging with changes in prey abundance (Diana 1990; Jacobs et al. 2013). Great Lakes Chinook Salmon have been observed to forage on Bloaters when Alewives are scarce (Rybicki and Clapp 1996), but Bloaters only represented 4\% of dietary wet weight during 2009-2011 and were consumed no more frequently than other salmonids.

Lake Trout diets during 2009-2011 differed from those found by most other recent studies. During 1983-1986, Lake Huron Lake Trout had a greater prevalence of Alewives in 

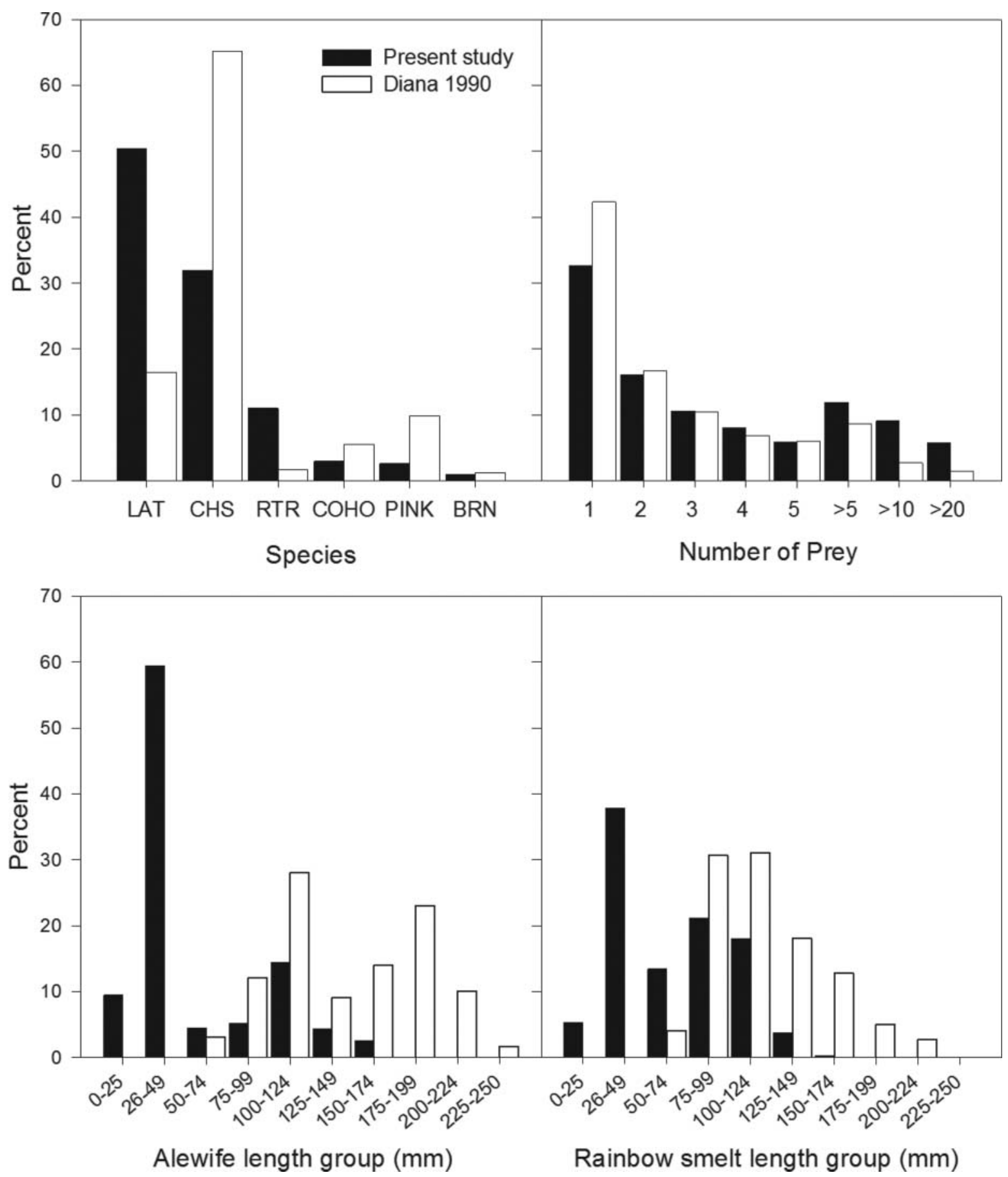

FIGURE 7. Comparison of species composition, number of prey in stomachs, and size distributions of Alewives and Rainbow Smelt in predator stomachs between samples taken during 2009-2011 and those obtained during 1983-1986 (Diana 1990). See Figure 2 for species abbreviations.

their diets than Chinook Salmon, and the only other species commonly consumed was Rainbow Smelt (Diana 1990). Likewise, other more recent studies in Lakes Michigan and Huron have found heavy reliance on Alewives with secondary predation on Rainbow Smelt (Madenjian et al. 2006, 2010; Jacobs et al. 2010). In contrast, Lake Ontario Lake Trout likely replaced Rainbow Smelt with Round Goby between 1992 and 2008 (Mills et al. 2003; Rush et al. 2012). In our study, Rainbow Smelt were still important but Round Goby was 50\% more important numerically and of equal importance by weight. Surprisingly, salmonids were encountered in about 5\% of Lake Trout and comprised almost $10 \%$ of dietary mass; we 

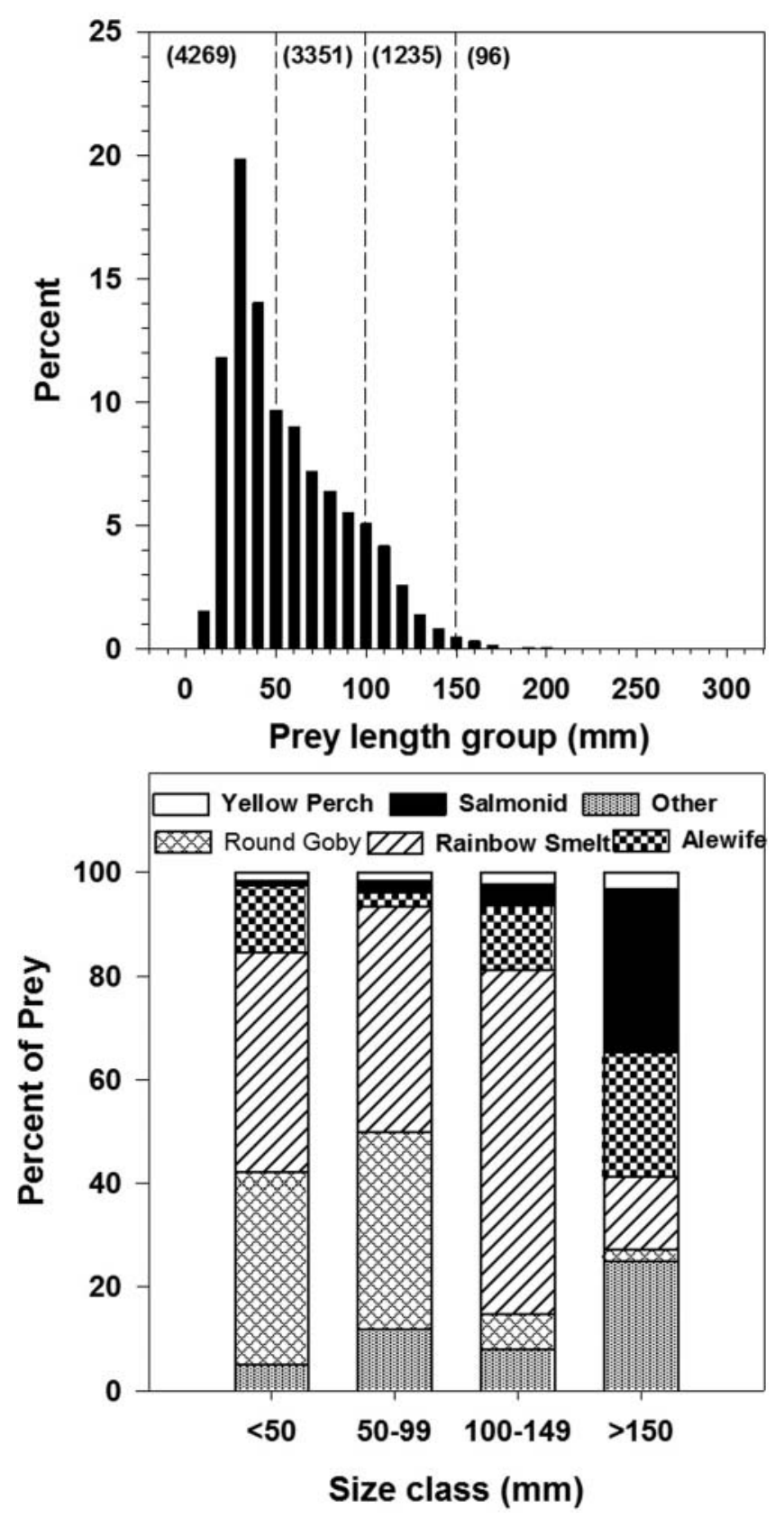

FIGURE 8. Prey size distributions in predator stomachs, Lake Huron, 20092011. Panel (A) shows the size distribution of 8,961 measured prey fish, panel (B) the species composition of prey size-classes. The sample sizes of the different size-classes are given in parentheses in the top panel but apply to both panels.

also observed a wide range of other fish prey not observed in previous studies.

The Walleye diets in our study differed from those in other studies in the Great Lakes, which found a preference for softrayed fishes, particularly clupeids and shiners (Parsons 1971; Knight et al. 1984; Hartman and Margraf 1992, 1993). However, those studies were undertaken under conditions in which prey biomass was high or Walleye populations were low;
Walleyes consumed spiny-rayed fishes only at times of low prey abundance (Knight and Vondracek 1992). Our study found that Yellow Perch made up a higher proportion of the dietary weight for Walleyes, which is consistent with low prey abundance. The walleye diets in our study also differed from those collected from Saginaw Bay during 1986-1988; at that time, Walleyes consumed predominantly clupeids and shiners and Yellow Perch were rare in their diets (Schaeffer 1994).

Comparisons of the diets of Atlantic Salmon, Coho Salmon, Pink Salmon, and Rainbow Trout between our study and other studies in the Great Lakes were limited because those species have generally been a small proportion of angler catches relative to Chinook Salmon and Lake Trout. But in prior studies of angler-caught fish diets all four species were dominated by Alewives or Rainbow Smelt, although Coho Salmon and Rainbow Trout had low numbers of invertebrates present (Diana 1990; Savitz 2009). Rand et al. (1993) found high dietary proportions of insects in Rainbow Trout, but predominantly in age-1 and age-2 fish that were likely smaller than those sampled in our study. Our results differed from those of prior studies in that those four species now consume substantial numbers of invertebrates (primarily terrestrial insects); the frequency of invertebrates ranged from about 5\% (Atlantic Salmon) to 47\% (Rainbow Trout) of diets, with most invertebrate biomass coming from terrestrial insects. The dietary composition of prey fish also differed. Although all salmonids consumed Alewives or Rainbow Smelt if those species were available, we observed that other species, such as Emerald Shiners and sticklebacks, are now of greater importance, especially for Coho Salmon and Atlantic Salmon.

Among-species comparisons of ration size were inconsistent with other independent field observations, but this was likely an artifact of dietary differences rather than among-species differences in consumption. In particular, Chinook Salmon had a higher ration size than most other species, yet Chinook Salmon growth was poor under the feeding conditions present during 2009-2011 (Johnson and Gonder 2013). Ration size was calculated only from fish that had eaten measurable amounts of food, and Chinook Salmon had a higher frequency of empty stomachs than all other species but Walleyes. Thus, ration size likely did not reflect overall consumption. Among-year differences in ration size likely did reflect changes in prey abundance, especially during 2011, but most mean ration size estimates were less than $0.5 \%$, which was lower than the $0.5-1.3 \%$ observed in Lake Michigan Lake Trout feeding predominantly on Alewives during 1994-1995 (Madenjian et al. 1998), when larger and preferred prey were likely more abundant. Overall, low mean ration size estimates are consistent with our hypothesis that prey availability was low via a combination of reduced prey biomass and lower availability of large (>150-mm) prey, but comparisons among species revealed little.

Our study relied entirely on angler-caught fish that we assumed were representative of the population. This 
assumption may have been violated because angling could be selective for actively foraging fish over a narrow depth range; traditionally, most anglers have fished by trolling near the thermocline with lures trailed behind downriggers (Diana 1990). However, comparisons between fishery-independent and fishery-dependent samples have been inconsistent. Hagar (1984) found lower prey diversity in angled fish, Brandt (1986) found higher diversity, and Jacobs et al. (2013) found no substantive dietary differences between angled and gill-net-captured Chinook Salmon. That bias, if present, might alter our estimates of dietary contributions among prey types or amongpredator differences in diet composition, but it would not change our conclusion that prey availability has changed substantially from earlier studies due to the greater importance of invertebrates and prey species other than Alewives and Rainbow Smelt that were formerly rare in or absent from diets (Diana 1990).

Temporal differences in fishing regulations may also have influenced our results. We compared diets and prey size during 1983-1986 with those observed during 2009-2011. During 1984-1986 the Lake Trout fishery closed on August 15, but during 2009-2011 it remained open until October. Thus, our comparisons included fish from unequal temporal windows. This is unlikely to have affected our conclusion that Lake Trout have become benthic predators for two reasons: (1) in both studies most fish were taken prior to August and (2) the temporal dietary differences likely arose from long-term changes between sampling periods rather than from seasonal changes within the sampling periods. In our study Lake Trout consumed Round Goby, which were not detected in the Great Lakes prior to 1991 (Jude et al. 1992) and which did not become widespread in Lake Huron until the late 1990s (Schaeffer et al. 2005). Thus, they were not present during Diana's (1990) 1983-1986 study.

Angling regulations and seasonal trends influenced the sizes and locations of fish collected by anglers. All salmon were subject to a 254-mm minimum size limit and all Walleyes to a 381-mm minimum size limit; Lake Trout were subject to different limits depending on location (a 381-mm minimum size limit in statistical districts $\mathrm{MH}-3,-4$, and -5 ; a 559-mm minimum size limit in statistical district $\mathrm{MH}-2$; and a slot length limit with a $685-\mathrm{mm}$ maximum [but with a trophy exception of one fish exceeding $813 \mathrm{~mm}$ ] in statistical district $\mathrm{MH}-1$ ); thus, our observations were confined to larger legal fish and did not extend to smaller size-groups. Furthermore, salmonids migrate north seasonally. The fishery begins in southern ports during May and progresses northward as spring and summer advance (Adlerstein et al. 2007). Thus, our seasonal and spatial comparisons were confounded and most of our salmonid observations represented summer captures from northern Lake Huron. However, this would be unlikely to influence our conclusion that diets had changed because Diana (1990) noted the same pattern.
Although Chinook Salmon are generalist predators in their native habitat, they appear to resist altering their foraging pattern in response to changes in prey availability, leading Jacobs et al. (2013) to describe them as having a dietary dependence on Alewives. Our study supports their view of extreme Alewife dependence, as Chinook Salmon continued to rely on them despite a 95\% reduction in Alewife biomass in Lake Huron during 1994-2007 (Roseman and Riley 2009), which was far more severe than the declines reported for Lake Michigan (which strained the predator-prey relationship there; Jacobs et al. 2013). Rainbow Smelt were also consumed but their biomass has declined as well, and even the availability of that alternative prey did not enable Chinook Salmon to thrive because both their growth and abundance have declined recently (Johnson and Gonder 2013). Conversely, other piscivores showed evidence of dietary plasticity that likely contributed to their ability to thrive or at least persist.

The piscivores in Lake Huron likely suffered reductions in prey size in addition to those in prey biomass. The unavailability of large prey may hinder fish from maintaining growth (Diana 1987; Mason et al. 1998), and this may have been exacerbated in Lake Huron because few prey $>150 \mathrm{~mm}$ were available. Alewives have also undergone reductions in energy density that likely required predators to eat more of them to sustain caloric intake (Jacobs et al. 2013). The loss of large prey may have exacerbated recent growth declines in Lake Trout, Chinook Salmon, and Walleyes (He et al. 2008; Fielder and Baker 2004).

All piscivores consumed some salmonids and Lake Trout were especially cannibalistic. Overall, salmonids were as important in Lake Trout diets as Alewives. This result was influenced strongly by a single sampling event during 2009, when anglers participating in a fishing tournament targeted their effort at an offshore reef that had received a stocking several days prior to the tournament; angler intent was to target the adult Lake Trout that had aggregated there subsequent to the stocking event. Nearly all of the Lake Trout in that sample had cannibalized recently stocked conspecifics, and some prey items were pristine enough for us to observe fin clips designating them as being of hatchery origin. However, we also observed predation or cannibalism at other sites in each year of the study. Our data suggest that poststocking predation is a substantial source of mortality for juvenile salmonids and may underlie an apparent recent decrease in the survival and harvest return of stocked salmonids.

Another significant change in predator diets from earlier studies was the increase in the number and biomass of invertebrates eaten. They dominated Rainbow Trout diets, and all salmonids consumed them to some degree. In some cases hundreds of insects were consumed by an individual, and we often observed pollen mixed with the insect carcasses, which suggests surface feeding. This likely occurred near thermal bars where "scum lines" of insects and wind-borne debris accumulate (Aultman and Haynes 1993). These areas are 
especially attractive to Rainbow Trout (Aultman and Haynes 1993), where they consume terrestrial insects (Brandt 1986). Our study was similar to those by Brandt (1986) and Rand et al. (1993) in that we also observed feeding on terrestrial insects (primarily ants and beetles) but differed in that the insect consumption in our study occurred later in the summer and by larger fish. Insects may represent an unrecognized terrestrial subsidy that could support higher predator biomass than would be predicted by previous food web models (Francis and Schindler 2009). However, the single whole-system study that we found suggests that insect subsidies in lakes represent only a small fraction of nutrient inputs (Mehner et al. 2005). High insect abundance in diets could also have been an artifact of anglers' concentrating their effort in relatively small areas of Lake Huron where insect fall occurred; scum lines are likely targeted by anglers because they represent the only visible surface feature in open water and most anglers are aware of their ability to concentrate Rainbow Trout. Nevertheless, the high consumption of insects appears to be a relatively recent phenomenon because most prior studies found few or no invertebrates in diets, especially for larger fish. The role of insect subsidies remains to be explored, but it could be important under current conditions.

Our results suggest that the piscivores we examined during 2009-2011 experienced chronic prey limitation. It is difficult to imagine how piscivore biomass could be enhanced under current conditions, and maintaining a large or thriving Chinook Salmon fishery in Lake Huron may be problematic in the absence of Alewives. In contrast, management strategies for other salmonids and Walleyes may be more successful because those species appear to be better able to take advantage of the existing prey base. The problem of cannibalism or predation on juvenile salmonids remains; thus, managers may also need to consider strategies to reduce the vulnerability of stocked fish. These may include multiple approaches, such as rearing to larger sizes, acclimation, selection of stocking sites that minimize predation, and the use of pulse-stocking to overwhelm predator response. Additionally, Walleye predation on Yellow Perch may be severe enough to limit Yellow Perch recruitment (Hartman and Margraf 1993; Fielder and Thomas 2014). The management of all piscivores in Lake Huron will likely require consideration of the pervasive effects of food web changes, especially if Alewives remain scarce.

\section{ACKNOWLEDGMENTS}

We thank the many Lake Huron anglers, fishing clubs, and tournament masters who collected data for us, especially Frank Krist and Ken Merkel, who promoted the study and organized sample storage and pickup. We also thank the many fishing clubs who allowed us to sample their fishing tournaments or carried out tournament stomach collections. Michigan Department of Natural Resources creel clerks Julie Shafto and Ed Barr and USGS Great Lakes Science Center contract technicians Michaela Bosshard, Emily Bouckaert, Matt McLean, Amanda Preuhs, Jenny Sutherland, and Patricia Thompson assisted with stomach collections or laboratory processing. David Bennion, Robin DeBruyne, and Stacey Ireland assisted with preparation of figures and provided comments on earlier drafts of this manuscript. Funding support for this work was provided by Michigan Sea Grant, the USGS Great Lakes Science Center, and the Grand Rapids Steelheaders. This is contribution number 1872 of the USGS Great Lakes Science Center.

\section{REFERENCES}

Adlerstein, S. A., E. S. Rutherford, D. Clapp, J. A. Clevenger, and J. E. Johnson. 2007. Estimating seasonal movements of Chinook Salmon in Lake Huron from efficiency analysis of coded wire tag recoveries in recreational fisheries. North American Journal of Fisheries Management 27:792-803.

Aron, W. I., and S. H. Smith. 1971. Ship canals and aquatic ecosystems. Science 174:13-20.

Aultman, D. C., and J. M. Haynes. 1993. Spring thermal fronts and salmonine sport catches in Lake Ontario. North American Journal of Fisheries Management 13:502-510.

Barbiero, R. P., M. Balcer, D. C. Rockwell, and M. L. Tuchman. 2009. Recent shifts in the crustacean zooplankton community of Lake Huron. Canadian Journal of Fisheries and Aquatic Sciences 66:816-828.

Brandt, S. B. 1986. Food of trout and salmon in Lake Ontario. Journal of Great Lakes Research 12:200-205.

Brown, E. H. 1972. Population biology of Alewives, Alosa pseudoharengus, in Lake Michigan, 1949-70. Journal of the Fisheries Research Board of Canada 29:477-500.

Budd, J. W., T. D. Drummer, T. F. Nalepa, and G. L. Fahnenstiel. 2001. Remote sensing of biotic effects: zebra mussels (Dreissena polymorpha) influence on water clarity in Saginaw Bay, Lake Huron. Limnology and Oceanography 46:213-223.

Bunnell, D. B., B. M. Davis, D. M. Warner, M. A. Chriscinske, and E. F. Roseman. 2011. Planktivory in the changing Lake Huron zooplankton community: Bythotrephes consumption exceeds that of Mysis and fish. Freshwater Biology 56:1281-1296.

Bunnell D. B., C. P Madenjian, and R. M. Claramunt. 2006. Long-term changes in the Lake Michigan fish community following the reduction of the exotic Alewife (Alosa pseudoharengus). Canadian Journal of Fisheries and Aquatic Sciences 63:2434-2446.

Carpenter, S. R., and J. F. Kitchell. 1988. Consumer control of lake productivity. BioScience 38:764-769.

Diana, J. S. 1987. Simulation of mechanisms causing stunting in Northern Pike populations. Transactions of the American Fisheries Society 116:612-617.

Diana, J. S. 1990. Food habits of angler-caught salmonines in western Lake Huron. Journal of Great Lakes Research 16:271-278.

Ebener, M. P., J. E. Johnson, D. M. Reid, N. P. Payne, R. L. Argyle, G. M. Wright, K. Krueger, J. P. Baker, T. Morse, and J. Weise. 1995. Status and future of Lake Huron fish communities. Pages 125-170 in M. Munawar, T. Edsall, and J. Leach, editors. The Lake Huron ecosystem: ecology, fisheries, and management. SPB Academic Publishing, Amsterdam.

Elliott, R. F., M. P. Ebener, R. W. Rybicki, P. J. Schneeberger, R. J. Hess, J. T. Francis, G. W. Eck, and C. P. Madenjian. 1996. Conducting diet studies of Lake Michigan piscivores: a protocol. U.S. Fish and Wildlife Service, Report 96-3, Green Bay, Wisconsin.

Eshenroder, R. L., and M. K. Burnham-Curtis. 1999. Species succession and sustainability of the Great Lakes fish community. Pages 145-184 in W. W. Taylor and C. P. Ferreri, editors. Great Lakes fisheries policy and management. Michigan State University Press, East Lansing. 
Fahnenstiel, G. L., G. A. Lang, T. F. Nalepa, and T. H. Johengen. 1995. Effects of zebra mussel (Dreissena polymorpha) colonization on water quality parameters in Saginaw Bay, Lake Huron. Journal of Great Lakes Research 21:435-448.

Fielder, D. G., and J. P. Baker. 2004. Strategy and options for completing the recovery of Walleye in Saginaw Bay, Lake Huron. Michigan Department of Natural Resources, Fisheries Special Report 29, Ann Arbor.

Fielder, D. G., and M. V. Thomas. 2014. Status and trends of the fish community of Saginaw Bay, Lake Huron, 2005-2011. Michigan Department of Natural Resources, Fisheries Research Report 03, Lansing.

Francis, T. B., and D. E. Schindler. 2009. Shoreline urbanization reduces terrestrial insect subsidies to fishes in North American Lakes. Oikos 118:1872-1882.

Hansen, M. J. 1999. Lake Trout in the Great Lakes: basinwide stock collapse and binational restoration. Pages $417-454$ in W. W. Taylor and C. P. Ferreri, editors. Great Lakes fisheries policy and management. Michigan State University Press, East Lansing.

Hagar, J. M. 1984. Diets of Lake Michigan salmonids and assessment of the dynamics of predator-prey interactions. Master's thesis. University of Wisconsin, Madison.

Hartman, K. J., and F. J. Margraf. 1992. Effects of prey and predator abundances on prey consumption and growth of Walleyes in western Lake Erie. Transactions of the American Fisheries Society 121:245-260.

Hartman, K. J., and F. J. Margraf. 1993. Evidence of predatory control of Yellow Perch (Perca flavescens) recruitment in Lake Erie, U.S.A. Journal of Fish Biology 43:109-119.

He, J. X., J. R. Bence, J. E. Johnson, D. F. Clapp, and M. Ebener. 2008. Modeling variation in mass-length relations and condition indices of Lake Trout and Chinook Salmon in Lake Huron: a hierarchical Bayesian approach. Transactions of the American Fisheries Society 137:801-817.

Hecky, R. E., R. E. H. Smith, D. R. Barton, S. J. Guildford, W. D. Taylor, M. N. Charlton, and T. Howell. 2004. The nearshore phosphorus shunt: a consequence of ecosystem engineering by dreissenids in the Laurentian Great Lakes. Canadian Journal of Fisheries and Aquatic Sciences 61:1285-1293.

Hyslop, E. J. 1980. Stomach content analysis: a review of methods and their application. Journal of Fisheries Biology 17:411-429.

Jacobs, G. R., C. P. Madenjian, D. B. Bunnell, and J. D. Holuszko. 2010. Diet of Lake Trout and Burbot in northern Lake Michigan during spring: evidence of ecological interaction. Journal of Great Lakes Research 36:312317.

Jacobs, G. R., C. P. Madenjian, D. B. Bunnell, D. M. Warner, and R. M. Claramunt. 2013. Chinook Salmon foraging patterns in a changing Lake Michigan. Transactions of the American Fisheries Society 142:362-372.

Johnson, J. E., and D. Gonder. 2013. Status of introduced salmonines. Pages 50-59 in S. C. Riley, editor. The state of Lake Huron in 2010. Great Lakes Fisheries Commission, Special Publication 13-01, Ann Arbor, Michigan.

Jude, D. J., and S. F. DeBoe. 1996. Possible impact of gobies and other introduced species on habitat restoration efforts. Canadian Journal of Fisheries and Aquatic Sciences 53(Supplement 1):136-141.

Jude, D. J., R. H. Reider, and G. R. Smith. 1992. Establishment of Gobiidae in the Great Lakes basin. Canadian Journal of Fisheries and Aquatic Sciences 49:416-421.

Jude, D. J., F. J. Tesar, S. F. Deboe, and T. J. Miller. 1987. Diet and selection of major prey species by Lake Michigan salmonines, 1973-1982. Transactions of the American Fisheries Society 116:677-691.

Knight, R. L., F. J. Margraf, and R. F. Carline. 1984. Piscivory by Walleyes and Yellow Perch in western Lake Erie. Transactions of the American Fisheries Society 113:677-693.

Knight, R. L., and B. Vondracek. 1992. Changes in prey fish populations in western Lake Erie, 1969-1988, as related to Walleye, Stizostedion vitreum, predation. Canadian Journal of Fisheries and Aquatic Sciences 50:12891298.
Kocik, J. F., and M. L. Jones. 1999. Pacific salmonines in the Great Lakes basin. Pages $455-487$ in W. W. Taylor and C. P. Ferreri, editors. Great Lakes fisheries policy and management. Michigan State University Press, East Lansing.

Madenjian, C. P., T. J. DeSorcie, and R. M. Stedman. 1998. Ontogenic and spatial patterns in diet and growth of Lake Trout in Lake Michigan. Transactions of the American Fisheries Society 127:236-252.

Madenjian, C. P., G. L. Fahnenstiel, T. H. Johengen, T. F. Nalepa, H. A. Vanderploeg, G. W. Fleischer, P. J. Schneeberger, D. M. Benjamin, E. B. Smith, J. R. Bence, E. S. Rutherford, D. Lavis, D. M. Robertson, D. J. Jude, and M. P. Ebener. 2002. Dynamics of the Lake Michigan food web, 1970-2000. Canadian Journal of Fisheries and Aquatic Sciences 59:736-753.

Madenjian, C. P., J. D. Holuszko, and T. J. DeSorcie. 2006. Spring-summer diet of Lake Trout on Six Fathom Bank and Yankee Reef in Lake Huron. Journal of Great Lakes Research 32:200-208.

Madenjian, C. P., S. A. Pothoven, P. J. Schneeberger, M. P. Ebener, L. C. Mohr, T. F. Nalepa, and J. R. Bence. 2010. Dreissenid mussels are not a "dead end" in Great Lakes food webs. Journal of Great Lakes Research 36 (Supplement 1):73-77.

Mason, D. M., T. B. Johnson, and J. F. Kitchell. 1998. Consequences of prey fish community dynamics on Lake Trout (Salvelinus namaycush) foraging efficiency in Lake Superior. Canadian Journal of Fisheries and Aquatic Sciences 55:1273-1284.

McNickle, G. G., M. D. Rennie, and W. G. Sprules. 2006. Changes in benthic invertebrate communities of South Bay, Lake Huron, following invasion by zebra mussels (Dreissena polymorpha) and potential effects on Lake Whitefish (Coregonus clupeaformis) diet and growth. Journal of Great Lakes Research 32:180-193.

Mehner, T., J. Ihlau, H. Dörner, and F. Holker. 2005. Can feeding of fish on terrestrial insects subsidize the nutrient pool of lakes? Limnology and Oceanography 50:2022-2031.

Michigan Department of Natural Resources. 2014. Michigan 2014 fishing guide. Michigan Department of Natural Resources, Lansing. Available: http://www. michigan.gov/dnr/0,4570,7-153-10364_63235-274824--,00.html. (September 2014).

Mills, E. L., J. M. Casselman, R. Dermott, J. D. Fitzsimons, G. Gal, K. T. Holeck, J. A. Hoyle, O. E. Johannsson, B. F. Lantry, J. C. Makarewicz, E. S. Millard, I. F. Munawar, M. Munawar, R. O'Gorman, R. W. Owens, L. G. Rudstam, T. Schane, and T. J. Stewart. 2003. Lake Ontario: food web dynamics in changing ecosystem (1970-2000). Canadian Journal of Fisheries and Aquatic Sciences 60:471-490.

Mittlebach, G. G., A. M. Turner, D. J. Hall, J. E. Rettig, and C. W. Osenberg. 1995. Perturbation and resilience: a long-term, whole-lake study of predator extinction and reintroduction. Ecology 76:2347-2360.

Nalepa, T. F., D. L. Fanslow, S. A. Pothoven, A. J. Foley III, and G. A. Lang. 2007. Long-term trends in benthic macroinvertebrate populations in Lake Huron over the past four decades. Journal of Great Lakes Research 33:421436.

Parsons, J. W. 1971. Selective food preferences of Walleyes of the 1959 yearclass in Lake Erie. Transactions of the American Fisheries Society 100:474-485.

Rand, P. S., D. J. Stewart, P. W. Seelbach, M. L. Jones, and L. R. Wedge. 1993. Modeling steelhead population energetics in Lakes Michigan and Ontario. Transactions of the American Fisheries Society 122:977-1001.

Riley, S. C., E. F. Roseman, M. A. Chriscinske, T. R. Tucker, J. Ross, P. Armenio, N. Watson, and W. Woelmer. 2014. Status and trends of the Lake Huron offshore demersal fish community, 1976-2013. U.S. Geological Survey, Annual Report to the Great Lakes Fishery Commission, Ann Arbor, Michigan.

Riley, S. C., E. F. Roseman, S. J. Nichols, T. P. O’Brien, C. S. Kiley, and J. S. Schaeffer. 2008. Deepwater demersal fish community collapse in Lake Huron. Transactions of the American Fisheries Society 137:1879-1890. 
Roseman, E. F., and S. C. Riley. 2009. Biomass of deepwater demersal forage fishes in Lake Huron, 1994-2007: implications for offshore predators. Aquatic Ecosystem Health Management 12:29-36.

Roseman, E. F., J. S. Schaeffer, and P. Steen. 2009. Review of fish diversity in the Lake Huron basin. Aquatic Ecosystem Health Management 12:11-22.

Rush, S. A., G. Paterson, T. B. Johnson, K. G. Drouillard, G. D. Haffner, C. E. Hebert, M. T. Arts, J. D. McGoldrick, S. M. Backus, B. F. Lantry, J. R. Lantry, T. Schaner, and A. T. Fisk. 2012. Long-term impacts of invasive species on a native top predator in a large lake system. Freshwater Biology 57:2342-2355.

Rybicki, R. W., and D. F. Clapp. 1996. Diet of Chinook Salmon in eastern Lake Michigan, 1991-93. Michigan Department of Natural Resources, Fisheries Division Research Report 2027, Lansing.

SAS Institute. 2011. Base SAS 9.3 procedures guide: statistical procedures. SAS Institute, Cary, North Carolina.

Savitz, J. 2009. Diets of Lake Michigan salmon and maximum size of Alewife prey. Journal of Freshwater Ecology 24:563-566.

Schaeffer, J. S. 1994. Mechanisms regulating growth and food consumption of Walleyes and Yellow Perch in Saginaw Bay, Lake Huron. Doctoral dissertation. University of Michigan, Ann Arbor.

Schaeffer, J. S., A. Bowen, M. Thomas, J. R. P. French III, and G. L. Curtis. 2005. Invasion history, proliferation, and offshore diet of Round Goby Neogobius melanostomus in western Lake Huron, USA. Journal of Great Lakes Research 31:414-425.

Schneider, J. C., editor. 2000. Manual of fisheries survey methods II with periodic updates. Michigan Department of Natural Resources, Fisheries Special Report 25, Lansing.
Smith, S. H. 1970. Species interactions of Alewife in the Great Lakes. Transactions of the American Fisheries Society 99:754-765.

Spangler, G. R., and J. J. Collins. 1992. Lake Huron fish community structure based on gill-net catches corrected for selectivity and encounter probability. North American Journal of Fisheries Management 12:585-597.

Stewart, D. J., J. F. Kitchell, and L. B. Crowder. 1981. Forage fishes and their salmonid predators in Lake Michigan. Transactions of the American Fisheries Society 110:751-763.

Tanner, H. A., and W. H. Tody. 2002. History of the Great Lakes salmon fishery: a Michigan perspective. Pages 139-154 in K. D. Lynch, M. L. Jones, and W. W. Taylor, editors. Sustaining North American salmon: perspectives across regions and disciplines. American Fisheries Society, Bethesda, Maryland.

Traynor, D., A. Moerke, and R. Greil. 2010. Identification of Michigan fishes using cleithra. Great Lakes Fishery Commission, Special Publication 20102, Ann Arbor, Michigan.

Warner, D. M., C. S. Kiley, R. M. Claramunt, and D. F. Clapp. 2008. The influence of Alewife year-class strength on prey selection and abundance of age-1 Chinook Salmon in Lake Michigan. Transactions of the American Fisheries Society 137:1683-1700.

Werner, E. E., and D. J. Hall. 1988. Ontogenetic habitat shifts in Bluegill: the foraging rate-predation risk trade-off. Ecology 69:1352-1366.

Wilmer, P. G., and D. M. Unwin. 1981. Field analyses of insect heat budgets: reflectance, size, and heating rates. Oecologia 50:250-255.

Zaret, T. M., and R. T. Paine. 1973. Species introduction in a tropical lake. Science 182:449-455. 